\section{Ethephon Seed Treatment Impacts on Drought Tolerance of Kentucky Bluegrass Seedlings}

\author{
Na Zhang ${ }^{1}$, Lu Han ${ }^{1}$, Lixin $\mathrm{Xu}^{1,3}$, and Xunzhong Zhang ${ }^{2,3}$
}

ADDITIONAL INDEX WORDs. drought stress, antioxidant enzyme, lipid peroxidation

SUMMARY. Ethephon [ETH (2-chloroethylphosphonic acid, an ethylene-releasing compound)] has been used as a plant growth regulator in turfgrass management. The aim of the study was to assess the effects of ETH seed treatment on drought tolerance of kentucky bluegrass (Poa pratensis) seedlings. Seeds of two kentucky bluegrass cultivars, Midnight and Nuglade, were exposed to ETH treatment or untreated as controls. Seedlings were then exposed to two water regimes: wellwatered conditions and polyethylene glycol (PEG)-induced drought conditions. ETH-treated plants exhibited better turf performance relative to the untreated control under PEG-stressed conditions illustrated by higher relative water content (RWC) and lower lipid peroxidation and lower electrolyte leakage (EL). In both cultivars, ETH treatment increased enzyme activity of ascorbate peroxidase (APX), peroxidase (POD), and catalase (CAT); proline content; and soluble protein content under PEG-induced drought conditions. The results suggest that ETH seed treatment can improve drought tolerance in kentucky bluegrass seedlings.

K entucky bluegrass, a perennial grass species, is widely used for both turf and forage. Drought stress is one of the major factors affecting growth, function, and turf performance of kentucky bluegrass in water-limited areas. Extensive studies have shown that application of trinexapac-ethyl could improve water use efficiency in turfgrasses (Burgess and Huang, 2014; Etemadi et al., 2015; Hejl et al., 2015; Roohollahi et al., 2010). The potential of using other plant growth regulators to promote plant performance under drought conditions has also been evaluated and reported, including salicylic acid (Ahmed et al., 2014), abscisic acid (ABA) (Khan et al., 2012), and auxin-simulating growth promoters (Bingham and McCabe, 2006; Burgess and Huang, 2014).

Ethephon is an important plant growth regulator which is used in crops and vegetables to induce flowering (Duyvelshoff and Cline, 2013; Garcia et al., 2008) and enhance fruit maturation (Goldschmidt, 1998; Rony

\footnotetext{
This work was supported by the Fundamental Research Funds for the Central Universities. Thanks are extended to David Jespersen for his kind assistance in language editing of this manuscript.

${ }^{1}$ Institute of Turfgrass Science, Beijing Forestry University, Beijing 100083, China

${ }^{2}$ Department of Crop and Soil Environmental Sciences, Virginia Polytechnic Institute and State University, Blacksburg, VA 24061

${ }^{3}$ Corresponding authors. E-mail: lixinxu@bjfu.edu.cn or xuzhang@vt.edu.
}

https://doi.org/10.21273/HORTTECH03976-18 et al., 2013). Ethephon penetrates into plant tissues and is then further translocated, where it decomposes to ethylene, the active substance (Zhang and Wen, 2010). Ethylene affects a variety of processes throughout the plant including stress responses (Wang et al., 2013). Ethylene-mediated growth enhancement can improve plant performance under adverse conditions (Pierik et al., 2007; Yang et al., 2013; Yu et al., 2001). Therefore, ETH might be a candidate for potentially improving plant tolerance to stresses. Morgan et al. (1977) pointed out that ETH treatment might also result in the accumulation of endogenous ABA, an inducer of a wide spectrum of antistress pathways in plants. Many reports confirmed that ETH played a key role in promoting plant tolerance to biotic stress. ETH treatgrapevine [Vitis vinifera (Belhadj et al., 2008)], mature tomato [Soluanum lycopersicum (Wang et al., 2011)], and banana [Musa acuminate (Tang et al., 2010)] by mediating the expression of ment induced disease resistance in different pathogenesis-related genes. Moreover, ETH treatment stimulated the gene expression of phospholipase $D$ (implicated in several responses to stress) following mechanical wounding in $\mathrm{cu}^{-}$ cumber [Cucumis sativus (Peng and Mao, 2011)]. Ethephon enhanced the germination of tassel flower [Amaranthus caudatus (Bialecka and Kepczynski, 2009, 2010)] and cucumber (Chang et al., 2010) seeds.

There are quite a few studies investigating the effect of ETH application on drought responses in plants, but the results are inconsistent, being dependent on plants' genetics, intensity, and duration of drought treatment and many other unknown factors. For instance, Kasele et al. (1994) revealed that under drought conditions, ETH application increased corn (Zea mays) yield at high plant densities, whereas it decreased yield at low plant densities. Shekoofa and Eman (2008) reported that the yield response of corn to ETH varied with plant density and available water. Zhang and Kirkham (1990) showed that ETH treatment increased the turgor potential of drought-sensitive cultivars of sorghum (Sorghum bicolor) but not of drought-resistant ones. Kirkham (1983) also found that ETH treatment did not increase resistance to drought in winter wheat (Triticum aestivum). Moreover, excessive ETH application induced oxidative stress (Xu et al., 2012), which might have negative effects on plant abiotic stress tolerance.

To minimize the oxidative damage induced by drought and other environmental stresses, plants have evolved various enzymatic and nonenzymatic mechanisms to detoxify harmful oxygen species, including enzymes that combat superoxide $\left(\mathrm{O}_{2}^{-}\right)$ and hydrogen peroxide $\left(\mathrm{H}_{2} \mathrm{O}_{2}\right)$, such as superoxide dismutase (SOD), CAT, and POD (Smirnoff, 1993). Ascorbate peroxidase is a $\mathrm{H}_{2} \mathrm{O}_{2}$-scavenging

\begin{tabular}{llll}
\hline $\begin{array}{l}\text { Units } \\
\text { To convert U.S. to SI, } \\
\text { multiply by }\end{array}$ & U.S. unit & SI unit & $\begin{array}{l}\text { To convert SI to U.S., } \\
\text { multiply by }\end{array}$ \\
\hline 0.1 & $\mathrm{bar}$ & $\mathrm{MPa}$ & 10 \\
29.5735 & $\mathrm{fl} \mathrm{oz}$ & $\mathrm{mL}$ & 0.0338 \\
2.54 & inch $(\mathrm{es})$ & $\mathrm{cm}$ & 0.3937 \\
28.3495 & $\mathrm{oz}$ & $\mathrm{g}$ & 0.0353 \\
0.001 & $\mathrm{ppm}$ & $\mathrm{mg} \cdot \mathrm{g}^{-1}$ & 1000 \\
1 & $\mathrm{ppm}$ & $\mathrm{mg} \cdot \mathrm{L}^{-1}$ & 1 \\
1 & $\mathrm{ppm}$ & $\mu \mathrm{g} \cdot \mathrm{g}^{-1}$ & 1 \\
$\left({ }^{\circ} \mathrm{F}-32\right) \div 1.8$ & ${ }^{\circ} \mathrm{F}$ & ${ }^{\circ} \mathrm{C}$ & $\left({ }^{\circ} \mathrm{C} \times 1.8\right)+32$
\end{tabular}


enzyme that is unique to plants and is indispensable to protect chloroplasts and other cellular constituents from damage caused by $\mathrm{H}_{2} \mathrm{O}_{2}$ and hydroxyl radicals $(\cdot \mathrm{HO})$ produced from it (Asada, 1992). Better turf quality in kentucky bluegrass under drought has been related to increases in antioxidant activities (Fu and Huang, 2001; Xu et al., 201la). Proline, an amino acid, plays a highly beneficial role in plants when they are exposed to various stress conditions (Hayat et al., 2012). Besides acting as an excellent osmolyte, proline plays three major roles during stress; i.e., as a metal chelator, an antioxidative defense molecule and a signaling molecule (Hayat et al., 2012). As osmolytes, soluble proteins also play an important role in maintaining leaf turgor and promoting the root's ability to uptake more water under drought (Wu et al., 2015). Ethephon might affect the drought tolerance of plants by mediating changes in antioxidant enzyme activity, and proline and soluble protein metabolism. Iqbal et al. (2017) conclude that ETH regulated proline and antioxidant metabolism under salinity stress to increase photosynthetic function in mustard (Brassica juncea). Ozturk and Demir (2003) showed that under saline conditions, ETH increased CAT activities and proline content but decreased POD activity. Kim et al. (2016) proved that the presence of ETH led to significantly higher levels of proline in a green alga (Chlorella vulgaris). Yu et al. (2017) also found that ETH significantly increased the accumulation of proline and the activities of SOD, POD, and CAT which in turn improved corn performance under drought stress. Zhang et al. (2013) demonstrated that ETH application promoted root hair development in trifoliate orange (Poncirus trifoliate), which could be beneficial to plants' response to drought.

In the turf industry, foliar application of ETH has been used to suppress seed head numbers and vegetative growth in a few turfgrass species (Fry, 1991). Jiang and Fry (1998) indicated that foliar application of ETH could increase the turf quality of perennial ryegrass under drought. The efficacy of using ETH as a seed treatment to promote drought resistances of turfgrass seedlings has not been widely studied.
For this work, we investigated physiological parameters in seedlings of two kentucky bluegrass cultivars under drought and well-watered conditions to analyze if ETH seed treatment can alter antioxidant enzyme activity, and proline and soluble protein content, and if this affects drought tolerance in kentucky bluegrass seedlings.

\section{Materials and methods}

Plant Materials AND GROWING conDitions. Seeds of kentucky bluegrass cultivars Midnight and Nuglade were surface sterilized in $1 \%$ sodium hypochlorite $(\mathrm{NaClO})$ for $5 \mathrm{~min}$ and then washed in sterilized water. Seeds of both cultivars were either immersed in $100 \mathrm{~mL}$ of $150 \mathrm{mg} \cdot \mathrm{L}^{-1}$ ETH solution for $24 \mathrm{~h}$ or in $100 \mathrm{~mL}$ of distilled water for $24 \mathrm{~h}$ for ETH treatment and control, respectively. The ETH concentration of $150 \mathrm{mg} \cdot \mathrm{L}^{-1}$ was used based on our previous study where it had maximum effect (Han, 2014). Afterward, the seeds were put onto sieves in plastic containers (length $45 \mathrm{~cm}$, width $30 \mathrm{~cm}$, and depth $25 \mathrm{~cm}$ ) filled with half-strength Hoagland solution (Hoagland and Arnon, 1950) and maintained in hydroponic culture in a greenhouse for 1 month. Seedlings were grown at an average temperature of $25^{\circ} \mathrm{C}$ under a $16 / 8 \mathrm{~h}$ (light/dark) photoperiod, with a light intensity of $600 \mu \mathrm{mol} \cdot \mathrm{m}^{-2} \cdot \mathrm{s}^{-1}$. The hydroponic solution was aerated by small aquarium air pumps (Atman EP-9000; Chuangxing Electrical Appliance Co., Zhongshan, China). Hoagland solution was replaced with fresh solution every week.

TREATMENT AND EXPERIMENTAL DESIGN. Seedlings of both ETHtreated, and non-ETH-treated control plants were grown until the fourth leaf was fully expanded and the first leaf was $\approx 13 \mathrm{~cm}$ long during the 1 -month period of the experiment. All the seedlings were exposed to one of two water regimes: 1) wellwatered conditions, in which seedlings were growing in half-strength Hoagland solution and 2) PEG-induced drought conditions, in which seedlings were growing in half-strength Hoagland solution plus PEG 6000 (30\%; Beijing Kebaiao, Beijing, China). Water potential of the PEG solution was $-1.20 \mathrm{MPa}$ (Steuter et al., 1981). The $\mathrm{pH}$ of all solutions was adjusted to 6.0.
The seedlings were maintained under different water regimes for $10 \mathrm{~d}$. Ethephon treatment and water regimes were arranged as a completely randomized block design with four replications. Each replication was many seedlings pooled for sampling.

RWC AND EL. Physiological changes observed in kentucky bluegrass plants were evaluated by measuring leaf RWC and cellular membrane stability expressed as EL. Measurements took place at 0,5 , and $10 \mathrm{~d}$ after the initiation of water regime treatments. Leaf RWC was determined based on three weights from collected tissues; fresh weight $[\mathrm{FW}(\approx 0.15 \mathrm{~g})]$, dry weight (DW), and turgid weight (TW) using the formula RWC (percent) = $[(\mathrm{FW}-\mathrm{DW}) /(\mathrm{TW}-\mathrm{DW})] \times 100$. Leaves were collected from plants and immediately weighed for determination of $\mathrm{FW}$. Samples were then immersed in deionized water and kept in dark for $12 \mathrm{~h}$ at $4{ }^{\circ} \mathrm{C}$ after which they were removed from deionized water, gently blotted dried, and weighed for TW. The samples were then dried in an oven set to $80^{\circ} \mathrm{C}$ for at least $72 \mathrm{~h}$ and weighed for DW (Barrs and Weatherley, 1962). To measure EL, fresh leaves $(0.1 \mathrm{~g})$ were rinsed with deionized water to remove external solutes, and immersed in $20 \mathrm{~mL}$ deionized water. Initial conductivity of the solution $\left(C_{\text {initial }}\right)$ was measured using a conductivity meter (DDSJ-318; Hinotek Instrument, Shanghai, China) following incubation in deionized water for $24 \mathrm{~h}$ on a shaker (HY-5; Ronghua, Jintan, China). Leaf samples were then autoclaved at $121{ }^{\circ} \mathrm{C}$ for $15 \mathrm{~min}$ and cooled at room temperature for final conductivity $\left(C_{\max }\right)$ measurement. EL percentage was then calculated as $\left(C_{\text {initial }} / C_{\max }\right) \times 100$ (Blum and Ebercon, 1981).

ANTIOXIDANT ENZYME ACTIVITY AND LIPID PEROXIDATION. Fully expanded leaf blades were excised and then wrapped in foil paper, immersed in liquid nitrogen, and stored at $-20{ }^{\circ} \mathrm{C}$ until measurement was determined. Determination of enzyme activity was carried out using the method previously described by Xu et al. (201la). Briefly, $0.25 \mathrm{~g}$ of fresh leaf tissue was frozen in liquid nitrogen and then ground to a fine powder using a mortar and pestle, and the extraction was performed with $4 \mathrm{~mL}$ of extraction buffer $(50 \mathrm{~mm}$ potassium phosphate, $1 \mathrm{~mm}$ ethylenediaminetetraacetic acid, 1\% polyvinylpyrrolidone, and $1 \mathrm{~mm}$ dithiothreitol; $\mathrm{pH}$ 
of 7). The extractions were centrifuged at $15,000 g_{\mathrm{n}}$ for $30 \mathrm{~min}$ at $4{ }^{\circ} \mathrm{C}$ and the supernatant was collected for enzyme assays and malondialdehyde (MDA) content measurement. The SOD [Enzyme Commission (EC) number: 1.15.1.1] activity was measured by recording the rate of $\mathrm{p}$-nitro blue tetrazolium chloride reduction
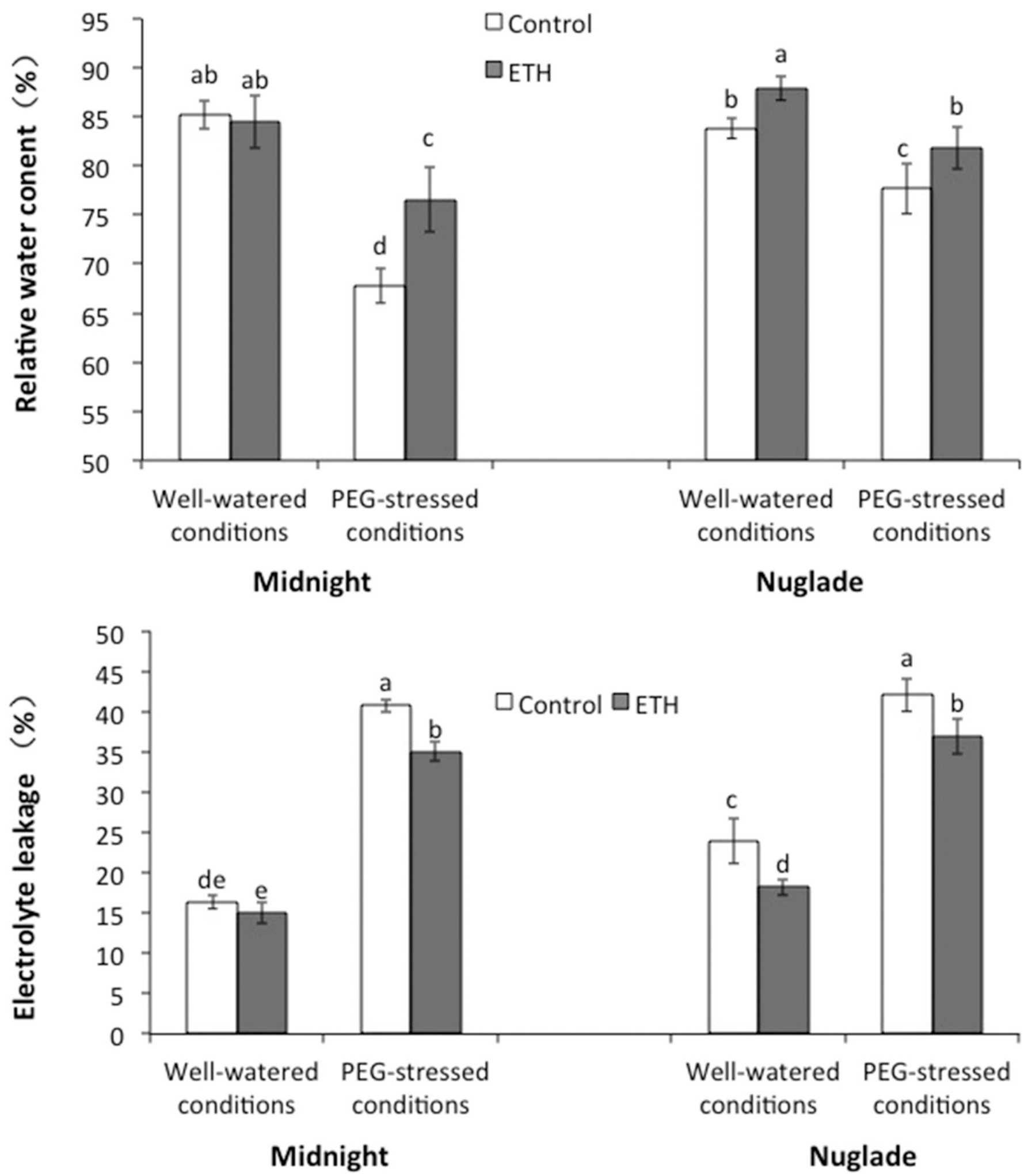

Fig. 1. Effect of ethephon (ETH) seed treatment on relative water content and electrolyte leakage of kentucky bluegrass cultivars Midnight and Nuglade under well-watered and polyethylene glycol (PEG)-stressed conditions. Control represents distilled water-treated control plants and ETH represents ETH-treated plants. Bars indicate \pm SD $(n=4)$. Bars which have the same letter indicate no significant difference $(P \leq 0.05)$ according to Fishers protected least significant difference test. 
based on absorbance at $560 \mathrm{~nm}$ using a spectrophotometer (Biomate 3S; Thermo Fisher Scientific, Waltham, MA). The activity of CAT; EC: 1.11.7.6, POD; EC: 1.11.1.7, and APX; EC: 1.11.1.1 was determined by following the $\mathrm{H}_{2} \mathrm{O}_{2}$ changes in absorbance at 240, 470, and $290 \mathrm{~nm}$, respectively. An absorbance change of 0.1 in 1 min was defined as one unit of enzyme activity. Lipid peroxidation was measured in terms of MDA content (Dhindsa and Matowe, 1981) with some modifications. A 1-mL aliquot of supernatant was mixed with $1 \mathrm{~mL}$ of $0.67 \%$ thiobarbituric acid. The mixture was heated at $95{ }^{\circ} \mathrm{C}$ for 15 min, quickly cooled on ice, and then centrifuged at $10,000 \mathscr{g}_{\mathrm{n}}$ for $5 \mathrm{~min}$. The absorbance of the supernatant was read at 532 and $600 \mathrm{~nm}$. The concentration of MDA was calculated using an extinction coefficient of $155 \mathrm{~mm}^{-1} \cdot \mathrm{cm}^{-1}$ (Heath and Packer, 1968).

Proline and SOluble protein CONTENT. Randomly selected tillers from each treatment were harvested at 0,5 , and $10 \mathrm{~d}$ after the initiation of the water regime treatments. The samples were flash-frozen in liquid nitrogen for at least $\mathrm{l} \mathrm{h}$ and then stored at $-70{ }^{\circ} \mathrm{C}$ for measurement of proline content and soluble protein content. Proline content was determined as previously described (Bates et al., 1973). Soluble protein content was determined using Bradford's methods (Bradford, 1976).

Data analysis. Effects of PEG treatment and ETH seed treatment were determined by analysis of variance according to the general linear model procedure of SAS (version 9.0; SAS Institute, Cary, NC). Differences between means were separated by Fisher's protected least significance difference test at the 0.05 significance level.

\section{Results and discussion}

EFFECT OF ETH SEED TREATMENT ON RWC AND EL OF KENTUCKY BLUEGRASS UNDER PEGSTRESSED CONDITIONS. Relative water content has been widely used to determine the physiological water status of plants. The results of this study indicated that PEG reduced RWC to $68 \%$ for 'Midnight' and $78 \%$ for 'Nuglade' (Fig. 1). Liu et al. (2006) also reported a gradual decrease of RWC in wheat cultivars after application of PEG. Under PEGstressed conditions, ETH-treated 'Midnight' maintained a higher RWC of $76.6 \%$, relative to the control (67.8\%) (Fig. 1). 'Nuglade' had a higher RWC of $81.8 \%$ with ETH treatment compared with the untreated controls $77.7 \%$ under PEGstressed conditions. ETH-treated plants had higher RWC in both cultivars under PEG stress compared with control plants. It is reported that plants with higher RWC under drought stress may have greater drought resistance (Schonfeld et al., 1988; Xu et al., 2011b). Our results suggested that ETH seed treatment might improve drought tolerance in both cultivars through improving plant water status. It has been observed that ethylene can influence stomatal responses via cross talk with ABA (Daszkowska-Golec and Szarejko, 2013; Desikan et al., 2006). ETH seed treatment might regulate stomatal responses which play critical roles in maintaining cell turgor and physiological functions, particularly during plant dehydration. EL has been widely used to estimate cell membrane stability (Blum and Ebercon, 1981). PEG treatment increased EL in both cultivars (Fig. 1). ETHtreated plants had lower EL values than the control plants for both cultivars under PEG-stressed conditions (35\% relative to $41 \%$, and $37 \%$ relative to $42 \%$ for 'Midnight' and 'Nuglade' respectively) (Fig. 1). Our results indicated that ETH seed treatment alleviated membrane damages caused by PEG stress. Yu et al. (2017) also found that ETH improved membrane stability in corn seedlings. Under nonstressed control conditions, ETH seed treatment reduced EL values for 'Nuglade' but not for 'Midnight', possibly because the cultivar sensitivity to ethylene may be different between the two. Previous studies also revealed that mustard cultivars with different ethylene sensitivities responded to ETH treatment differently (Iqbal et al., 2012).

EFFECT OF ETH SEED TREATMENT ON LIPID PEROXIDATION AND ANTIOXIDANT ENZYME ACTIVITIES OF KENTUCKY BLUEGRASS UNDER PEG-STRESSED CONDITIONS. Drought stress induced by PEG increased lipid peroxidation, measured as MDA content in leaves, compared with well-water conditions (Fig. 2). ETH treatment reduced MDA levels relative to the control under PEGstressed conditions. This suggests that ETH treatment may improve antioxidant activity in kentucky bluegrass seedlings (Xu et al., 201la).

Ethephon seed treatment promoted higher levels of SOD activity relative to control under well-watered conditions for 'Midnight' and under PEG-stressed conditions for 'Nuglade' (Fig. 3). Under PEG-stressed conditions, ETH increased SOD activity of

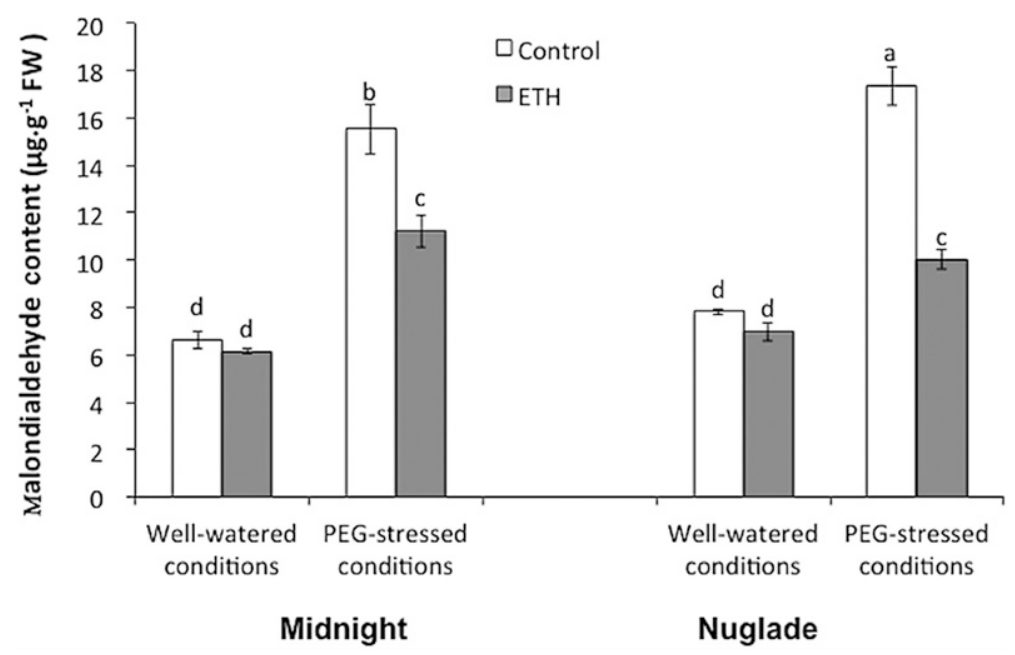

Fig. 2. Effect of ethephon (ETH) seed treatment on malondialdehyde of kentucky bluegrass cultivars Midnight and Nuglade under well-watered and polyethylene glycol (PEG)-stressed conditions. Control represents distilled water-treated control plants and ETH represents ETH-treated plants. Bars indicate $\pm \operatorname{SD}(n=4)$. Bars which have the same letter indicate no significant difference $(P \leq 0.05)$ according to Fishers protected least significant difference test; $1 \mu \mathrm{g} \cdot \mathrm{g}^{-1}=1 \mathrm{ppm}$. 
'Nuglade' by $48 \%$, compared with controls. This result suggested that ETH treatment improved the plant's ability to combat $\mathrm{O}_{2}^{-}$under PEGstressed conditions for 'Nuglade' but not for 'Midnight'. It also confirmed that the ways in which SOD responds to ETH treatment varies between cultivars. CAT activities were increased by ETH treatment under both well-watered and PEGstressed conditions in both cultivars (Fig. 3) compared with their respective controls. It is worthy to note that under PEG-stressed condition, ETH treatment prompted $\approx 133 \%$ and $41 \%$ higher CAT activity for 'Midnight' and 'Nuglade'. In agreement with our results, Ozturk and Demir (2003) found that ETH treatment increased CAT activities in salt-stressed spinach leaves. In addition, ETH seed treatment promoted higher enzyme activity of
POD (Fig. 3) and APX (Fig. 3) under PEG-induced drought conditions. Many studies have revealed that ethylene responsive factors (ERFs) play important roles in conferring plant stress tolerance by promoting gene expression of CAT and other defense-related genes $(\mathrm{Li}$ et al., 2012; Sewelam et al., 2013; Wu et al., 2008). ETH treatment might trigger expression of ERFs, which in turn enhance the expression of antioxidant genes. In general, higher levels of antioxidant enzyme activity in ETH-treated seedlings indicate that the ability to scavenge for singlet oxygen and $\mathrm{H}_{2} \mathrm{O}_{2}$ in kentucky bluegrass was enhanced by ETH treatment, which may result in less free radical-mediated damage, including lipid peroxidation (demonstrated by MDA production, Fig. 2) and improve plant drought tolerance.
EFFECT OF ETH SEED TREATMENT ON PROLINE CONTENT IN KENTUCKY BLUEGRASS UNDER PEGSTRESSED CONDITIONs. Polyethylene glycol treatment increased proline content $\approx 3$-fold in comparison with the control under well-watered conditions in both cultivars (Fig. 4). Ethephon treatment increased proline content in both cultivars under PEG-stressed conditions compared with well-watered controls. It is well known that proline accumulates in plants during adaptation to various types of abiotic stresses (e.g., drought). Grzesiak et al. (2013) also reported that proline could be the most important osmoprotectant in osmotic stress induced by PEG. Our data support that proline accumulation in plants has a protective function (Fig. 4). It is suggested that $\mathrm{ABA}$ plays a vital role in proline synthesis/accumulation (Hare et al., 1999), and ETH seed
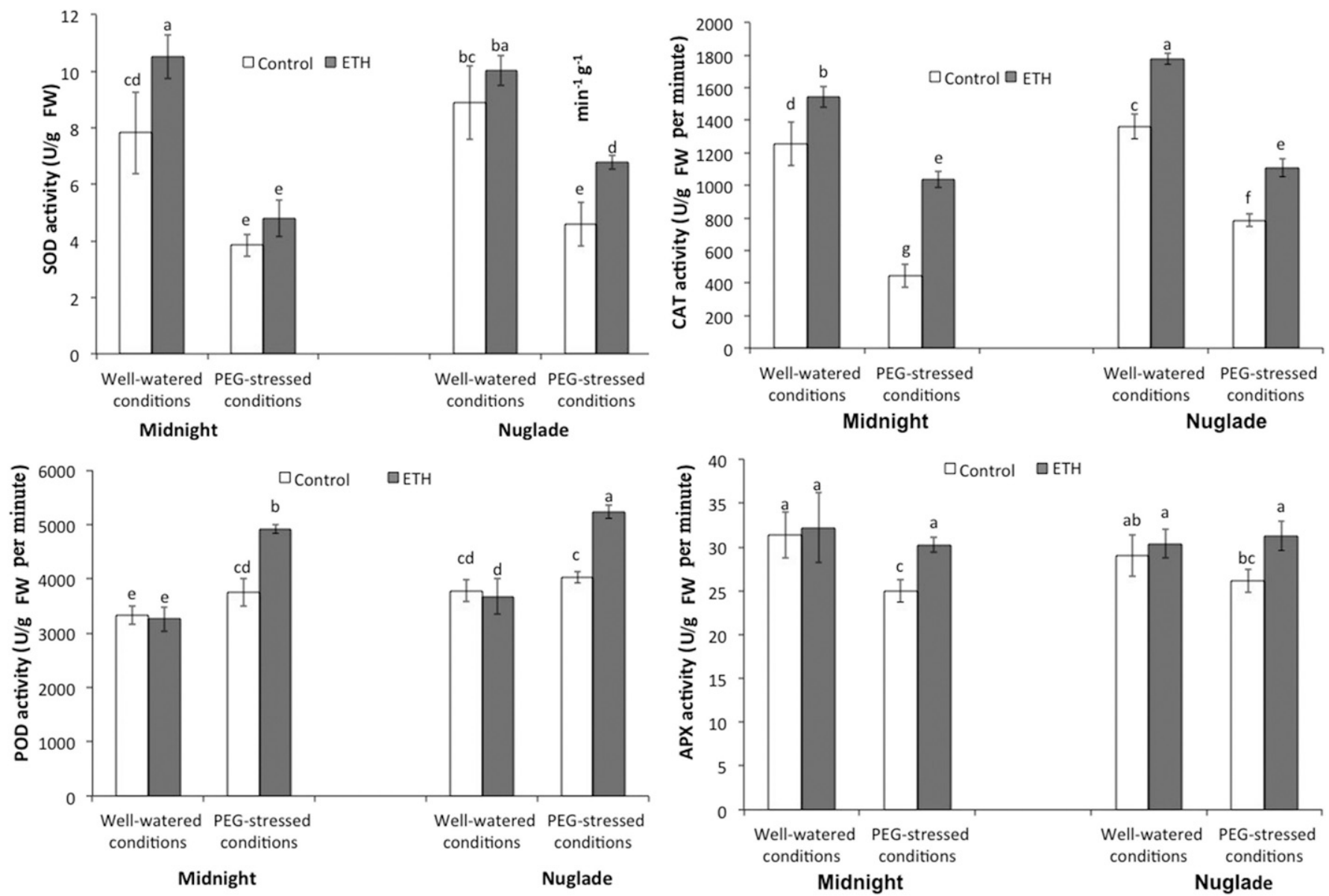

Fig. 3. Effect of ethephon (ETH) seed treatment on activity of superoxide dismutase (SOD), catalase (CAT), peroxidase (POD), and ascorbate peroxidase (APX) in kentucky bluegrass cultivars Midnight and Nuglade under well-watered and polyethylene glycol (PEG)-stressed conditions. Control represents distilled water-treated control plants and ETH represents ETH-treated plants. Bars indicate \pm SD $(n=4)$. Bars which have the same letter indicate no significant difference $(P \leq 0.05)$ according to Fishers protected least significant difference test; $1 \mathrm{U} / \mathrm{g}=\mathbf{2 8 . 3 4 9 5} \mathrm{U} / \mathrm{oz}$. 


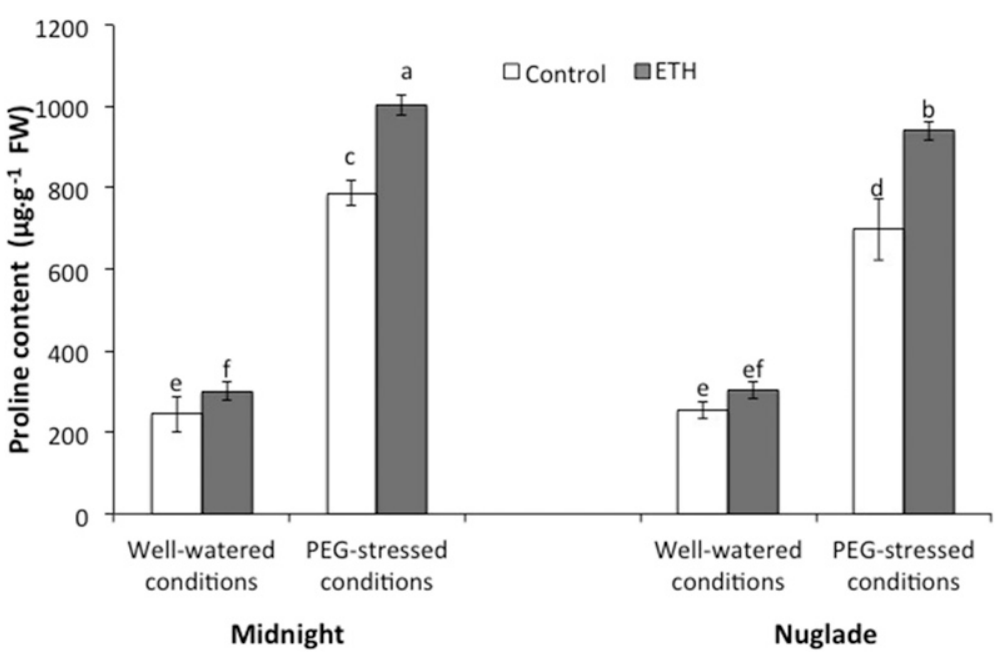

Fig. 4. Effect of ethephon (ETH) seed treatment on proline content in kentucky bluegrass cultivars Midnight and Nuglade under well-watered and polyethylene glycol (PEG)-stressed conditions. Control represents distilled water-treated control plants and ETH represents ETH-treated plants. Bars indicate $\pm \operatorname{SD}(n=4)$. Bars which have the same letter indicate no significant difference $(P \leq 0.05)$ according to Fishers protected least significant difference test; $1 \mu \mathrm{g} \cdot \mathrm{g}^{-1}=1 \mathrm{ppm}$.

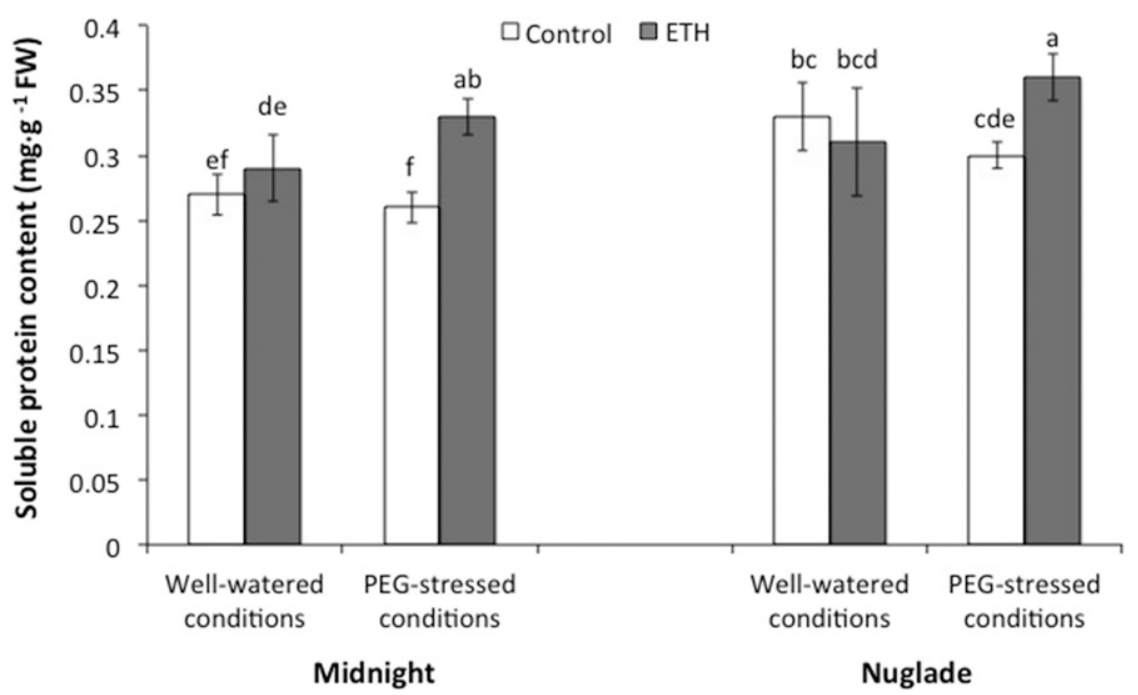

Fig. 5. Effect of ethephon (ETH) seed treatment on soluble protein content in kentucky bluegrass cultivars Midnight and Nuglade under well-watered and polyethylene glycol (PEG)-stressed conditions. Control represents distilled water-treated control plants and ETH represents ETH-treated plants. Bars indicate $\pm \mathrm{SD}(n=4)$. Bars which have the same letter indicate no significant difference $(P \leq 0.05)$ according to Fishers protected least significant difference test; $1 \mathrm{mg} \cdot \mathrm{g}^{-1}=1000 \mathrm{ppm}$.

treatment might increase ABA synthesis/ accumulation, which activates proline synthesis (Verbruggen and Hermans, 2008) and other stress defense pathways in a coordinated manner.

EFFECT OF ETH SEED TREATMENT ON SOLUBLE PROTEIN CONTENT IN KENTUCKY BLUEGRASS UNDER PEG-STRESSED CONDITIONS. Ethephon-treated seedlings of both kentucky bluegrass cultivars showed greater soluble protein content than nontreated plants in response to PEGinduced drought stress (Fig. 5). Plants adapt to drought stress via osmotic adjustment through the accumulation of soluble proteins and proline, as well as other compatible solutes (Blum, 2017). In this study, the soluble protein (Fig. 5) and proline contents (Fig. 4) were all increased with ETH seed treatment under PEG stress, which suggested that ETH seed treatment might contribute to enhancing osmotic adjustment by increasing the contents of soluble proteins and proline (Fig. 4) under PEG-induced drought stress. The increases in soluble protein content in ETH-treated 'Midnight' and 'Nuglade' over their respective control under PEG-stressed conditions were $30 \%$ and $22 \%$, respectively.

The generation of reactive oxygen species can cause the oxidation of amino acids and damage protein structure; therefore, oxidative stress might be responsible for the reduction of soluble proteins in kentucky bluegrass plants under PEG stress. Higher antioxidant enzyme activity promoted by ETH seed treatment (Fig. 3) provided better protection against oxidative damage induced by PEG stress which might cause less reduction in soluble protein content in ETH-treated plants.

In conclusion, ETH seed treatment might improve drought tolerance in kentucky bluegrass seedlings through promoting antioxidant enzyme activity and the accumulation of proline and soluble proteins. However, more research is needed to evaluate the efficacy of ETH on the improvement of drought tolerance in established kentucky bluegrass turf as well.

\section{Literature cited}

Ahmed, F., D.M. Baloch, S.A. Sadiq, S.S. Ahmed, A. Hanan, S.A. Taran, N. Ahmed, and M.J. Hassan. 2014. Plant growth regulators induced drought tolerance in sunflower (Helianthus annums L.) hybrids. J. Anim. Plant Sci. 24:886-890.

Asada, K. 1992. Ascorbate peroxidase: A hydrogen peroxide-scavenging enzyme in plants. Physiol. Plant. 85:235-241.

Barrs, H. and P. Weatherley. 1962. A reexamination of the relative turgidity technique for estimating water deficits in leaves. Austral. J. Biol. Sci. 15:413-428.

Bates, L.S., R.P. Waldren, and I.D. Teare. 1973. Rapid determination of free proline for water-stress studies. Plant Soil 39:205-207.

Belhadj, A., N. Telef, S. Cluzet, J. Bouscaut, M.F. Corio-Costet, and J.M. Merillon. 2008. Ethephon elicits protection against Erysiphe necator in grapevine. J. Agr. Food Chem. 56:5781-5787.

Bialecka, B. and J. Kepczynski. 2009. Effect of ethephon and gibberellin A3 on Amaranthus caudatus seed germination 
and $\alpha$ - and $\beta$-amylase activity under salinity stress. Acta Biologica Cracoviensia 51(2):119-125

Bialecka, B. and J. Kepczynski. 2010. Germination, $\alpha-, \beta$-amylase and total dehydrogenase activities of Amaranthus caudatus seeds under water stress in the presence of ethephon or gibberellin A3. Acta Biologica Cracoviensia 52(1):712.

Bingham, I.J. and V.B. McCabe. 2006. Commercially available plant growth regulators and promoters modify bulk tissue abscisic acid concentrations in spring barley, but not root growth and yield response to drought. Ann. Appl. Biol. 149:291-304.

Blum, A. 2017. Osmotic adjustment is a prime drought stress adaptive engine in support of plant production. Plant Cell Environ. 40:4-10.

Blum, A. and A. Ebercon. 1981. Cell membrane stability as a measure of drought and heat tolerance in wheat. Crop Sci. 21:43-47.

Bradford, M.M. 1976. A rapid and sensitive method for the quantitation of microgram quantities of protein utilizing the principle of protein-dye binding. Anal. Biochem. 72:248-254.

Burgess, P. and B.R. Huang. 2014. Effects of sequential application of plant growth regulators and osmoregulants on drought tolerance of creeping bentgrass (Agrostis stolonifera). Crop Sci. 54:837844.

Chang, C.S., B. Wang, L. Shi, Y.X. Li, L. Duo, and W.H. Zhang. 2010. Alleviation of salt stress-induced inhibition of seed germination in cucumber (Cucumis sativus L.) by ethylene and glutamate. J. Plant Physiol. 167:1152-1156.

Daszkowska-Golec, A. and I. Szarejko. 2013. Open or close the gate: Stomata action under the control of phytohormones in drought stress conditions. Front. Plant Sci. 4:138.

Desikan, R., K. Last, R. Harrett-Williams, C. Tagliavia, K. Harter, R. Hooley, J.T. Hancock, and S.J. Neill. 2006. Ethyleneinduced stomatal closure in Arabidopsis occurs via AtrbohF-mediated hydrogen peroxide synthesis. Plant J. 47:907-916.

Dhindsa, R.S. and W. Matowe. 1981. Drought tolerance in two mosses: Correlated with enzymatic defence against lipid peroxidation. J. Expt. Bot. 32:79-91.

Duyvelshoff, C. and J.A. Cline. 2013. Ethephon and prohexadione-calcium influence the flowering, early yield, and vegetative growth of young 'Northern
Spy' apple trees. Scientia Hort. 151:128134.

Etemadi, N., M.H. Sheikh-Mohammadi, A. Nikbakht, M.R. Sabzalian, and M. Pessarakli. 2015. Influence of trinexapac-ethyl in improving drought resistance of wheatgrass and tall fescue. Acta Physiol. Plant. 37:53.

Fry, J.D. 1991. Centipedegrass response to plant growth regulators. HortScience 26:40-42.

$\mathrm{Fu}, \mathrm{J}$. and B. Huang. 2001. Involvement of antioxidants and lipid peroxidation in the adaptation of two cool-season grasses to localized drought stress. Environ. Expt. Bot. 45:105-114.

Garcia, O.J., E.Y. Duenez, G. Fischer, B. Chaves, and O.C. Quintero. 2008. Effect of potassium nitrate, potassium phosphate and ethephon in floral induction of pineapple guava (Acca sellowiana O. Berg burret). Rev. Bras. Frutic. 30:577-584.

Goldschmidt, E.E. 1998. Ripening of citrus and other non-climacteric fruits: A role for ethylene. Acta Hort. 463:335340 .

Grzesiak, M., M. Filek, A. Barbasz, B. Kreczmer, and H. Hartikainen. 2013. Relationships between polyamines, ethylene, osmoprotectants and antioxidant enzymes activities in wheat seedlings after short-term PEG- and $\mathrm{NaCl}$-induced stresses. Plant Growth Regulat. 69:177189.

Han, L. 2014. Effects of ethephon treatment of drought resistance of Kentucky bluegrass (Poa pratensis. L). Beijing For. Univ., Beijing, China, Master's Diss.

Hare, P.D., W.A. Cress, and J. van Staden. 1999. Proline synthesis and degradation: A model system for elucidating stress-related signal transduction. J. Expt. Bot. 50:413434.

Hayat, S., Q. Hayat, M.N. Alyemeni, A.S Wani, J. Pichtel, and A. Ahmad. 2012. Role of proline under changing environments. Plant Signal. Behav. 7:14561466.

Heath, R.L. and L. Packer. 1968. Photoperoxidation in isolated chloroplasts: I. Kinetics and stoichiometry of fatty acid peroxidation. Arch. Biochem. Biophys. 125:189-198.

Hejl, R.W., B.G. Wherley, J.C. Thomas, and R.H. White. 2015. Irrigation water quality and trinexapac-ethyl effects on bermudagrass response to deficit irrigation. HortScience 50:1081-1087.

Hoagland, D.R. and D.I. Arnon. 1950 The water-culture method for growing plants without soil. California Agr. Expt. Sta. Circ. 347.
Iqbal, N., R. Nazar, M.I.R. Khan, and N.A. Khan. 2012. Variation in photosynthesis and growth of mustard cultivars: Role of ethylene sensitivity. Scientia Hort. 135:1-6.

Iqbal, N., S. Umar, T.S. Per, and N.A. Khan. 2017. Ethephon increases photosynthetic-nitrogen use efficiency, proline and antioxidant metabolism to alleviate decrease in photosynthesis under salinity stress in mustard. Plant Signal. Behav. 12: el297000.

Jiang, H. and J. Fry. 1998. Drought responses of perennial ryegrass treated with plant growth regulators. HortScience $33: 270-273$

Kasele, I.N., F. Nyirenda, J.F. Shanahan, D.C. Nielsen, and R. d'Andria. 1994. Ethephon alters corn growth, water use, and grain yield under drought stress. Agron. J. 86:283-288.

Khan, A., J. Bakht, A. Bano, and N.J. Malik. 2012. Response of groundnut (Arachis hypogaea L.) genotypes to plant growth regulators and drought stress. Pak. J. Bot. 44:861-865.

Kim, S-H., S.R. Lim, S-J. Hong, B-K. Cho, H. Lee, C-G. Lee, and H-K. Choi. 2016. Effect of ethephon as an ethylenereleasing compound on the metabolic profile of Chlorella vulgaris. J. Agr. Food Chem. 64:4807-4816.

Kirkham, M.B. 1983. Effect of ethephon on the water status of a drought-resistant and a drought-sensitive cultivar of winter wheat. Z. Pflanzenphysiol. 112:103-112.

Li, C., L.B. Han, and X.Z. Zhang. 2012. Enhanced drought tolerance of tobacco overexpressing OjERF gene is associated with alteration in proline and antioxidant metabolism. J. Amer. Soc. Hort. Sci. 137:107-113.

Liu, W.J., S. Yuan, N.H. Zhang, T. Lei, H.G. Duan, H.G. Liang, and H.H. Lin. 2006. Effect of water stress on photosystem 2 in two wheat cultivars. Biol. Plant. 50:597-602.

Morgan, P.W., W.R. Jordan, T.L. Davenport, and J.I. Durham. 1977. Abscission responses to moisture stress, auxin transport inhibitors, and ethephon. Plant Physiol. 59:710-712.

Ozturk, L. and Y. Demir. 2003. Effects of putrescine and ethephon on some oxidative stress enzyme activities and proline content in salt stressed spinach leaves. Plant Growth Regulat. 40:89-95.

Peng, Y. and L. Mao. 2011. Salicylic acid, ethephon, and methyl jasmonate induce the expression of phospholipase $\mathrm{D}$ in mechanically-wounded cucumber. J. Hort. Sci. Biotechnol. 86:235-240. 
Pierik, R., R. Sasidharan, and L.A.C.J. Voesenek. 2007. Growth control by ethylene: Adjusting phenotypes to the environment. J. Plant Growth Regulat. 26: $188-200$

Rony, A.H., M.S. Khan, A. Hasnat Md. Sazedur Rahman, and M. Islam. 2013. A critical analysis of artificial fruit ripening: Scientific, legislative and socio-economic aspects. Chem. Eng. Sci. Mag. 4(1):1-7.

Roohollahi, I., M. Kafi, and R. Naderi. 2010. Drought reaction and rooting characteristics in response to plant growth regulators on Poa pratensis cv. Barimpala. J. Food Agr. Environ. 8:285-288.

Schonfeld, M.A., R.C. Johnson, B.F. Carver, and D.W. Mornhinweg. 1988. Water relations in winter wheat as drought resistance indicators. Crop Sci. 28:526-531

Sewelam, N., K. Kazan, S.R. ThomasHall, B.N. Kidd, J.M. Manners, and P.M. Schenk. 2013. Ethylene response factor 6 is a regulator of reactive oxygen species signaling in Arabidopsis. PLoS One 8: e70289

Shekoofa, A. and Y. Eman. 2008. Effects of nitrogen fertilization and plant growth regulators (PGRs) on yield of wheat (Triticum aestivum L.) cv. Shiraz. J. Agr. Sci. Technol. 10(2):101-108.

Smirnoff, N. 1993. The role of active oxygen in the response of plants to water deficit and desiccation. New Phytol. 125:27-58.

Steuter, A.A., A. Mozafar, and J.R. Goodin. 1981. Water potential of aqueous polyethylene glycol. Plant Physiol. 67:64-67.
Tang, W., S. Zhu, L. Li, D. Liu, and D.E Irving. 2010. Differential expressions of PRI and chitinase genes in harvested bananas during ripening, and in response to ethephon, benzothiadizole and methyl jasmonate. Postharvest Biol. Technol. 57: 86-91.

Verbruggen, N. and C. Hermans. 2008. Proline accumulation in plants: A review. Amino Acids 35:753-759.

Wang, F.F., X.K. Cui, Y. Sun, and C.H. Dong. 2013. Ethylene signaling and regulation in plant growth and stress responses. Plant Cell Rpt. 32:1099-1109.

Wang, Y.Y., B.Q. Li, G.Z. Qin, L. Li, and S.P. Tian. 2011. Defense response of tomato fruit at different maturity stages to salicylic acid and ethephon. Scientia Hort. 129:183-188.

Xu, L., L. Han, and B. Huang. 201la. Antioxidant enzyme activities and gene expression patterns in leaves of Kentucky bluegrass in response to drought and post-drought recovery. J. Amer. Soc. Hort. Sci. 136:247-255.

Xu, L.X., L.B. Han, and B.R. Huang. 2011 b. Membrane fatty acid composition and saturation levels associated with leaf dehydration tolerance and post-drought rehydration in Kentucky bluegrass. Crop Sci. 51:273-281.

Wu, S., C. Hu, Q. Tan, L. Li, K. Shi, Y. Zheng, and X. Sun. 2015. Drought stress tolerance mediated by zinc-induced antioxidative defense and osmotic adjustment in cotton (Gossypium birsutum). Acta Physiol. Plant. 37:167.

Wu, L., Z. Zhang, H. Zhang, X-C. Wang, and R. Huang. 2008. Transcriptional modulation of ethylene response factor protein JERF3 in the oxidative stress response enhances tolerance of tobacco seedlings to salt, drought, and freezing. Plant Physiol. 148:1953-1963.

Xu, Y.W., D. Zhao, A.M. Husaini, L.L. Guan, and W. Wu. 2012. Ethephon induces monoterpene production and lipid oxidative stress in Houttuynia cordata Thunb. Philipp. Agr. Sci. 95:7-13.

Yang, L., Y.G. Zu, and Z.H. Tang. 2013. Ethylene improves Arabidopsis salt tolerance mainly via retaining $\mathrm{K}^{+}$in shoots and roots rather than decreasing tissue $\mathrm{Na}^{+}$ content. Environ. Expt. Bot. 86:60-69.

Yu, X.M., M. Griffith, and S.B. Wiseman. 2001. Ethylene induces antifreeze activity in winter rye leaves. Plant Physiol. 126: 1232-1240.

Yu, H., Y. Zhang, Y. Xie, Y. Wang, L. Duan, M. Zhang, and Z. Li. 2017. Ethephon improved drought tolerance in maize seedlings by modulating cuticular wax biosynthesis and membrane stability. J. Plant Physiol. 214:123-133

Zhang, J. and M.B. Kirkham. 1990. Water status of drought-resistant and droughtsensitive sorghum treated with ethephon. J. Plant Growth Regulat. 9:189-194.

Zhang, W. and C.K. Wen. 2010. Preparation of ethylene gas and comparison of ethylene responses induced by ethylene, ACC, and ethephon. Plant Physiol. Biochem. 48:45-53.

Zhang, D., R. Xia, X. Cao, B. Shu, and C. Chen. 2013. Root hair development of Poncirus trifoliata grown in different growth cultures and treated with 3 -indolebutyric acid and ethephon. Scientia Hort. 160:389397. 